\title{
El Debate del cálamo y la espada, de Jacob ben Eleazar de Toledo
}

\author{
Amparo Alba Cecilia* \\ Universidad Complutense de Madrid
}

\begin{abstract}
En el presente artículo ofrecemos la traducción y el estudio del capítulo cuarto del Sefer ha-Mešalim, colección de cuentos al estilo de las macamas compuesta por Jacob ben Eleazar de Toledo (siglo XIII); este capítulo, conocido como el Debate del cálamo y la espada, expone en forma alegórica la supremacía de las letras sobre las armas.

PALABRAS CLAVE: Jacob ben Eleazar; debates medievales; El cálamo y la espada.

The Debate between the Pen and the Sword, by Jacob ben Eleazar of Toledo.- In this article we offer a Spanish translation with a commentary of the fourth chapter of Sefer ha-Mešalim, a collection of tales written by Jacob ben Eleazar of Toledo ( $13^{\text {th }}$ century) in the style of Maqāma $\bar{t}$; this chapter, known as the Debate between the Pen and the Sword, shows, in an allegorical way, the supremacy of the arts over the arms.
\end{abstract}

Keywords: Jacob ben Eleazar; Medieval Religious Debate; The Pen and the Sword.

El Debate del cálamo y la espada, cuya traducción y estudio presentamos, forma parte de una colección de cuentos, Sefer ha-Mešalim, compuesta a comienzos del siglo XIII por Jacob ben Eleazar de Toledo.

Son pocos los datos biográficos conocidos sobre este autor, a pesar de que se le atribuye una docena de obras ${ }^{1}$. Parece que perteneció a una ilustre familia de Toledo, los Abenalazar, mencionada en varios documentos hispanojudíos ${ }^{2}$. Siguiendo la tradición de los nobles judíos, fue educado en la lengua y cultura árabes, además de en las suyas propias; destacó como gramático, filósofo, tra-

* aalba@ filol.ucm.es

${ }^{1}$ Una buena introducción al autor y su obra se puede ver en J. SchiRmann, The History of Hebrew Poetry in Christian Spain and Southern France. Edited, Supplemented and Annotated by E. Fleischer (hebreo) (Jerusalem 1997), págs. 222-255. Según Anónimo, Milon, ms. de S. Petersburgo Ms. 77, nuestro autor compuso doce obras de diversos temas: «R. Ya' aqob compuso el Sefer ha-Šalem llamado el auténtico [...] y tiene doce composiciones sobre temas diversos».

2 Eleazar no era, por tanto, el nombre de su padre, sino el nombre de su familia: Abenalazar. Ver Y. BAER, Tarbiz 5 (1934), pág. 232. Ver también ID., Historia de los judíos en la España cristiana. Traducción de J. L. LACAVE (Barcelona 1998), en cuyo índice aparecen frecuentemente mencionados los nombres Alazar, Abenalazar y Eleazar. 
ductor y poeta. Coetáneo de Al-Harizí, viajó, como éste y otros muchos escritores hebreos de su época, por tierras ibéricas y provenzales en busca de mecenas ${ }^{3}$ que le permitieran dedicarse a la actividad literaria: compuso, en árabe y en hebreo, diversas obras de carácter gramatical, filosófico o literario, y también realizó traducciones al hebreo de obras árabes.

En árabe compuso una obra lingüística, el Kitāb al-Kamil (Sefer ha-Šalem), que sólo nos es conocido en la actualidad por algunas citas ${ }^{4}$; como traductor, se le debe una versión hebrea del Calila e Dimna en prosa rimada, a partir de un original árabe 5; otras obras suyas son: Sefer Pardes Rimmoné ha-Hokná wa- 'arugat bosem ha-mezimmá, tratado filosófico en verso y en prosa que consta de 23 capítulos ${ }^{6}$ o el Sefer gan ha-te $u d o t$ (disputa entre el alma racional y el intelecto), obra ética y filosófica que compuso en su vejez ${ }^{7}$; pero su principal contribución en hebreo es, sin duda, la colección de diez cuentos escritos al estilo de las macamas de la que forma parte nuestro texto ${ }^{8}$.

El Sefer ha-Mešalim se ha conservado en un único manuscrito de la Biblioteca Estatal de Munich, el Cod. hebr. 207. Este manuscrito ${ }^{9}$, copiado en $1268{ }^{10}$ por Semayá bar Ya'aqob ha-Cohén, ha planteado graves problemas a los distintos es-

3 Entre los principales mecenas, mencionados en muchas de sus obras, se encuentran el médico, escritor y juez Benveniste ben Hiyya, que sufragó la traducción del Calila; y Semuel y 'Ezra, hijos de Yehudá b. Natanel de Beaucaire, en Provenza, a los que dedicó su obra de ética Gan Te 'udot.

${ }^{4}$ S. Poznanski, «Ein Citat aus Jacob ben Elazar's Kitab al-kamil», ZfHB II (1897), págs. 153-155. N. Allony identificó unos diez folios de esta obra, que publicó en su Yaqob ben Eleazar, Kitab al Kamil (Jerusalem 1977); ver también Y. BLAU, «He'arot le-text ule-targum šel 'Kitab al-Kamil' le-Ya'aqob ben El'azar», Tarbiz 49 (1977), págs. 164 ss.

${ }^{5}$ El texto de las dos versiones fue editado por J. Derenbourg, Deux versions hébraïques du livre Kalilah et Dimnah (Paris 1881); estudios sobre dichas versiones, en A. NAVARro: «Las versiones hebreas de Calila y Dimna», Revista de Filología Románica 14, vol. 2 (1997), págs. 325-333, e ID., «La versión hebrea de Calila e Dimna de Ya'aqob ben El'azar», en J. Targarona Borrás y Á. SÁenz-Badillos (eds.), Jewish Studies at the Turn of the 20th Century (Leiden-Boston-Köln 1999), vol. II, págs. 468-475.

${ }^{6}$ Los capítulos 13-23 los publicó Davidson según el ms. de Cambridge T-S 18K 8/7, en Ha-șofé le-ḥoknat Yišrael 10 (1926), págs. 94-105, y 11 (1927), pág. 96. La obra va precedida de un poema introductorio de 33 versos: «Súplicas y plegarias».

7 Ver M. SteInschneIDER, «Zu Kalila we-Dimna», ZDMG 27 (1874), pág. 558 y Taḥkemoní, ed. de Y. Toporovsky (Tel Aviv 1952), cap. 46.

${ }^{8}$ El título de Sefer ha-Mešalim figura en la introducción del autor.

${ }^{9}$ Este manuscrito contiene, además del libro de Jacob ben Eleazar, el Sefer ha-Hayyim, de autor desconocido.

${ }^{10}$ Sobre la fecha del manuscrito, ver M. STEINSCHNEIDER, Die hebräischen Handschriften der K. Hof-und Staatsbibliothek in München (München 1895), págs. 88-90. 
tudiosos que se han acercado a él con intención de editarlo ${ }^{11}$; parece ser que el copista, no comprendiendo el texto original que tenía ante sí, realizó un trabajo lleno de erratas, de malas lecturas y de locuciones idiomáticas que él mismo inventó, lo que dificulta enormemente la comprensión del texto e incluso nos impide valorar adecuadamente la obra de Jacob ben Eleazar ${ }^{12}$. Hayyim Schirmann, que publicó más de la mitad de la obra ${ }^{13}$, fue el primero en valorar y apreciar el talento literario de su autor ${ }^{14}$. Finalmente la obra vio la luz en una nueva edición del manuscrito publicada en 1993 por Yonah David, quien se ayudó de las ediciones o transcripciones incompletas de Brody y Schirmann para presentar «una versión fiel del texto original» ${ }^{15}$. Desgraciadamente, tampoco esta edición resuelve los principales problemas que ya se habían puesto de manifiesto. Es cierto que el manuscrito es a veces ilegible, sobre todo, por la semejanza en cuanto al trazo de muchas letras. Tal y como sugirieron los investigadores anteriores, el copista parecía no entender bien lo que estaba copiando o su nivel lingüístico era «diferente» del esperado. Si a esto añadimos las erratas tipográficas de la edición, las correcciones de lecturas que el editor hace ${ }^{16}$ (ya sea del manuscrito, o de Brody, o de Schirmann) no

11 A. Geiger, el primero en emprender esa tarea, desistió enseguida, y expresó su opinión negativa sobre el libro en Oșar Neḥmad 2 (1857), pág. 161: «Desisto de transcribir más, pues estoy harto de [...] tanta palabrería sin sentido y de su lenguaje estrafalario e incomprensible».

${ }^{12}$ Lo que justifica que la mayoría de los especialistas que encontraron dificultades con la lectura del texto y su interpretación también manifestaron opiniones negativas sobre el libro. Así, por ej., Steinschneider dice en su Die hebräischen Übersetzungen des Mittelalters und die Juden als Dolmetscher (Berlin 1893), pág. 771, que todo lo que hay en el Sefer ha-Mešalim «son poemas de amor simbólicos, composiciones sobre el intelecto, sobre las tres almas y cosas parecidas expuestas de una forma artificial y aburrida». El mismo desánimo debió de experimentar Brody cuando emprendió la tarea de publicar el libro y, después de haberlo transcrito entero, sólo publicó tres poemas en su antología $\breve{S}$ 'ar ha-Šir, en H. Brody \& K. Albrecht, Ša 'ar ha-Šir. Die neuhebräische Dichterschule der Spanisch-arabischen Epoche (Leipzig 1905), págs. 162-165.

13 En el año 1939 publicó las macamas 5, 6, 7 y 9 y la Introducción del autor en «Sippuré haAhabá šel Ya'aqob b. Ele'azar», Studies of the Research Institute for Hebrew Poetry in Jerusalem V (Berlin-Jerusalem 1939), págs. 209-266; en 1973, publicó la macama n. 8 en «Ha-ša'ar hašeminí mi-Sefer ha-Mešalim le-Ya'aqob ben El'azar», Kovetz 'al-Yad 8 (1976), págs. 259-281, y un estudio de esta macama en «Ma'asé be-zaqen șabu'a», Studies in the History of Hebrew Poetry and Drama (hebreo) (Jerusalem 1973), págs. 375-378.

14 En «Ma'asé be-zaqen șabu'a»: «Después de haberlo trascrito entero, la breve introducción y los diez capítulos siguientes, se me hizo evidente que tenía ante mí una obra sin par en nuestra literatura de la Edad Media». Insiste en estos elogios y critica las opiniones negativas de Brody y de Steinschneider en «Les contes rimés de Jacob ben Eléazar de Tolède», en Études d'Orientalisme dédiées à la mémoire de Lévi-Provençal (Paris 1962), vol. I, págs. 285-297.

15 Y. DAVID, The Love Stories of Jacob ben Eleazar. Critical Edition with Introduction and Commentary (hebreo) (Tel Aviv 1992-93); anteriormente había editado algunas macamas en distintas publicaciones periódicas; la que nos ocupa apareció por primera vez en Katif 16-17 (1989), págs. 158-170.

16 En la introducción explica que ha corregido todas las lecturas erróneas de Schirmann y los errores del copista, recurriendo, en los casos más difíciles, a las lecturas de la trascripción de H. Brody. 
siempre acertadas ni justificadas y la escasez de notas aclaratorias, se comprende que la tarea de traducción resulte especialmente complicada. En las notas a pie de página, he señalado las erratas o, a mi juicio, lecturas incorrectas de esta edición, y he propuesto otras alternativas para ofrecer un texto coherente que refleje lo mejor posible la obra original.

La obra que tenemos ante nosotros comprende diez macamas ${ }^{17}$, y una introducción compuesta por el autor, en la que justifica su obra: «El motivo de mi libro de cuentos y de que lo componga en prosa rimada es que los sabios ismaelitas, sintiéndose amedrentados por la lengua santa, se envalentonaban y fanfarroneaban ante mí, y respondían con osadía diciendo: en nuestra lengua podemos componer todo tipo de proverbios, son los que dicen: "prevaleceremos por nuestra lengua”». Ante esto, sus amigos le rogaron que emprendiera la batalla de defender y salvaguardar la lengua hebrea, que había sido humillada. También reivindica su obra y su autoría, pues «siguiendo las costumbres de los ismaelitas de cambiarse los nombres en los relatos, no he mantenido mi nombre, sino que lo he cambiado por el de Lemuel ben Itiel, pero has de saber que yo soy Jacob ben Eleazar [...], y que el que me robe algo de esto, sea expulsado y aniquilado».

El Debate del cálamo y la espada constituye, pues, el cuarto capítulo, o la cuarta macama, del Sefer ha-Mešalim; en el encabezado encontramos: Disputa del cálamo y la espada; la espada es derrotada y escucha cuestiones de ética y filosofía de boca del cálamo ${ }^{18}$.

Se trata de una composición de unas doscientas líneas en prosa rimada con intercalación de poemas métricos y tres partes claramente diferenciadas: la primera es una introducción alegórica que sitúa el relato en una época donde «la generación de los necios creció y se multiplicó», y arrinconó a la sabiduría que tuvo que permanecer oculta en cuevas, hasta que se alzó con el trono un nuevo rey de nombre «profeta elocuente», amante de las ciencias y la poesía, que restauró a los sabios y persiguió a los necios. El narrador, convertido en protagonista de los sucesos que narra, describe su encuentro con la Sabiduría, una joven doncella «que no conoce varón», a la que desposa. El paso a la segunda parte -el debate propiamente dicho- es brusco:

${ }^{17}$ Las cuatro primeras son debates de tipo alegórico: la primera es un debate entre el alma y el cuerpo; la segunda, entre la poesía y la prosa; la tercera reproduce una justa poética en que distintos poetas compiten por componer los mejores poemas; la cuarta es un debate entre el cálamo y la espada por ver quién es más fuerte; las seis macamas restantes son cuentos de amor.

18 Sobre la importancia del debate como género literario en la Edad Media, en lengua árabe, hebrea o castellana, así como de los de los principales temas que aparecen tratados, ver E. Franchini, Los debates literarios en la Edad Media (Madrid 2001); A. Alba Cecilia, «El Debate de la espada y el cálamo», en Proyección histórica de España en sus tres culturas (Valladolid 1993), vol. III, págs 7-13; y EAD. «Espada vs. Cálamo: debates hispánicos medievales», Revista de Filología Francesa 11-12 [= Homenaje al Prof. Jesús Cantera] (1977), págs. 47-56. 
«Cuando la Sabiduría se dirigía a la casa de estudio en compañía de su esposo [...] vio a dos hombres que reñían»; se trata de los dos contendientes que protagonizan el resto de la macama: «El uno era un valiente guerrero; su rostro era como el de un león, ceñía una espada sujeta a sus caderas»; el otro no llevaba en la mano más que una humilde caña, pero acepta el desafío lanzado por el guerrero: «iTonto! Ponte la mano en la boca y cállate porque te puedo destruir con la boca de mi cálamo». Los contendientes son sustituidos por los instrumentos que los representan: comienza el debate entre el cálamo y la espada sobre sus respectivas virtudes; los argumentos que esgrimen siguen muy de cerca los tópicos acuñados por escritores anteriores ${ }^{19}$; la espada se burla del cálamo por sus orígenes humildes y por su debilidad, y el cálamo reprocha a la espada su violencia e ignorancia. El cálamo se declara como un arma mucho más poderosa que la espada por tener acceso a todos los conocimientos públicos y secretos; ante esto, la espada reconoce la superioridad del cálamo y le suplica que la ilustre con sus conocimientos.

Comienza entonces la tercera parte, una especie de pequeño tratado filosóficoteosófico acerca de la unicidad de Dios y sus cualidades, que el cálamo expone tras reconocer humildemente que es a Él, el creador de todo, al que pertenece la auténtica sabiduría. Termina el debate con el reconocimiento, por parte de la espada, de la superioridad de la sabiduría sobre cualquier otra cosa, pues como dice el Eclesiastés: «La sabiduría da más fuerza al sabio que diez poderosos» y «Más vale la sabiduría que todas las armas de guerra» ${ }^{20}$.

Schirmann puso de manifiesto las influencias foráneas en el Sefer ha Mešalim ${ }^{21}$, especialmente de la literatura árabe, pero también de la literatura en lengua romance o latina; en este capítulo en concreto, la oposición entre el hombre de letras (sofra) y el hombre de armas (sayafa) tiene antecedentes en literatura rabínica ${ }^{22}$, pero la forma de la disputa entre los dos contendientes en Ben Eleazar dista mucho de reflejar la tradición talmúdica, y sigue las formas y los gustos impuestos por la literatura árabe entre los autores hispanohebreos medievales ${ }^{23}$.

19 Ver AlBA, «Espada vs. Cálamo», págs. 50-51.

${ }^{20}$ Qo 7,19 y 9,18 .

${ }^{21}$ En «Les contes rimés», págs. 292-297; ver también en esta línea R. P. ScheindLin, «The Love Stories of Jacob ben Eleazar: Between Arabic and Romance Literature» (hebreo), en Proceedings of the Eleventh World Congress of Jewish Studies (Jerusalem 1994), vol. III, section C, págs.16-20.

22 En TB, AZ 17b se recoge la siguiente expresión atribuida a R. Eleazar b. Perata: «Si es hombre de espada, no es hombre de libro y si es hombre de libro no es hombre de espada».

${ }^{23}$ Ver, por ejemplo, la «Epístola de la espada y la pluma» de Ibn Burd al-Aṣgar, en F. de la Granja, Maqamas y risalas andaluzas (Madrid 1976), págs. 3-44; y la «Disputa del cálamo y la espada», en Judá ben Shelomo Al-Harizi, Las Asambleas de los Sabios (Taḥkemoní), ed. C. del Valle (Murcia 1988), págs. 263-266. 


\section{TRADUCCIÓN}

DEBATE DEL CÁLAMO Y LA ESPADA [La espada cae derrotada y escucha palabras de ética y filosofía de boca del cálamo]

Relato de Lemuel ben Itiel ${ }^{24}$ : Sucedió una vez que la generación de los necios ${ }^{25}$ creció y se multiplicó y la poesía ${ }^{26}$ se perdió y desapareció: murió o fue herida o robada ${ }^{27}$. $\mathrm{Y}$ el orbe engendró con profusión todo tipo de chusma vil ${ }^{28}$, porque estaba contaminado, se había corrompido ${ }^{29}$; el sabio no lograba ningún provecho ${ }^{30}$ como antaño ${ }^{31}$, y el destino ${ }^{32}$ lo despojó de sus más preciadas y ricas vestiduras: lo despojó de las suyas y le cubrió con otras ${ }^{33}$.

Entonces pronuncié estos versos ${ }^{34}$ :

La ignorancia se propagó por las calles, su huella se extendió como la lepra; se prostituyó con las hijas de la necedad y se enamoró locamente de su falta de juicio ${ }^{35}$;

${ }_{24}$ El pseudónimo bajo el que se esconde el autor (ver supra) está formado por la unión de dos nombres que aparecen en la Biblia: Lemuel, en Pr 31,1, e Itiel, en Pr 30,1; también en Ne 11,7 aparece el nombre Ben Itiel. Según Schirmann («Les contes rimés», pág. 293) el nombre de Itiel es una referencia al nombre del narrador de los cuentos en las Macamas de Al-Hariri traducidas por Yehudá al-Harizí (Maḥberot Itiel, ed. Y. Peretz, Tel-Aviv 1950).

25 Sobre la presencia del tópico del mundus inversus, representado en este relato por el dominio de la «generación de los necios» (dor ha-sijlut), ver A. NAVARRO, «El mundus inversus ("Olam hafuj') en el Sefer ha-Mešalim de Ya'acob ben El'azar de Toledo», en E. RomERo (ed.), Judaísmo Hispano: Estudios en memoria de José Luis Lacave Riaño (Madrid 2002), vol. I, págs. 209-215.

26 En el ms. השב; David, siguiendo a Brody, corrige a השיר.

27 Ex 22,9.

28 En la ed. y ms.: כל בן מנבל; quizás sea un error por כל בני נבל ('chusma vil'), sentido que encontramos en $\mathrm{Jb} 30,8$.

29 En el ms. תחבל; David corrige el ms. siguiendo a Brody, a לחבל. En mi opinión es preferible la lectura del ms. (תחבל) tal como figura en la cita bíblica de Mi 2,10 que utiliza el autor.

30 Qo 10,11

31 Gé 40,13.

32 En la ed.: המן. Se trata de una errata tipográfica por הזמן.

33 Le 6,4.

34 Todos los poemas van introducidos por la fórmula fija: וישא משלו ויאמר con variaciones en cuanto al sujeto que lo recita. Es la fórmula con la que Balaam introduce sus oráculos (cf. Nú 23,18; 24,3, etc.) y es también el modo habitual de introducir un poema en los escritos hebreos medievales en prosa rimada, al estilo de las macamas árabes. Metro hebreo del poema: ha-marnin.

35 Expresión muy frecuente en la Biblia, sobre todo en Pr, por ej., 6,32; 7,7; 9,4; 10,13. 
el necio, temeroso y envidioso de mí, cometió tropelías ${ }^{36}$ a mansalva,

y traspasó a la inteligencia de una lanzada

en el bajo vientre, llegándole hasta el fondo ${ }^{37}$.

El ignorante montó en cólera,

reclutó ejércitos de mentecatos ${ }^{38}$

y persiguió a la inteligencia,

la persiguió a ultranza, hasta que ella se escondió

y ya no se supo con certeza si estaba muerta,

herida o cautiva ${ }^{39}$.

Y dijo al profeta de la inteligencia:

¡Déjalo ya! ${ }^{40}$ ¿para qué profetizar

si la tierra estaba yerma

de inteligencia y talento? ${ }^{41}$

Los sabios rasgaron sus vestiduras ${ }^{42}$ y cegaron todos los manantiales ${ }^{43}$. Y así fue como la inteligencia vino a menos, se enturbió la fuente y se contaminó el manantial ${ }^{44}$.

Dije entonces el poema ${ }^{45}$ :

Los más necios del pueblo ${ }^{46}$ crecieron y se multiplicaron, entre ellos destacaban los que se daban a la bebida ${ }^{47}$.

Sellaron todas las fuentes de la sabiduría ${ }^{48}$

cegándolas, sin que se supiera dónde ${ }^{49}$ había una fuente,

${ }^{36}$ En la ed. y ms. הונות ('riquezas'); por contexto habría que corregir a הונאות ('injurias, ultrajes').

37 Cf. Nú 25,8.

38 En la ed. y ms. בערים ('en las ciudades'), proponemos בוערים ('necios, mentecatos').

39 Cf. Ex 22,9. El ms. ofrece una lectura distinta e incoherente, que David corrige siguiendo a Brody.

$402 \mathrm{Cr} 25,16$.

41 Cf. 1 Cr 22,12.

42 Cf. Le 10,6; el ms. añade: פאר ('de gala'), que David omite.

$432 \operatorname{Re} 3,25$.

$44 \operatorname{Pr} 25,26$.

45 Metro hebreo del poema: ha-mahir.

46 Sal 94,8.

47 Cf. Pr 23,20.

$482 \mathrm{Cr} 32,4$.

$49 \mathrm{Na} 3,17$. 
hasta que la necedad proclamó ${ }^{50}$ en la calle:

¿Queda algún sabio? respondieron: No.

¡Calla ${ }^{51}$, inteligencia, que tu salvación

llegará, oráculo del varón clarividente ${ }^{52}$ !

En el año $93{ }^{53}$, cuando habían llegado a colmo las prevaricaciones ${ }^{54}$ y el espíritu había revestido ${ }^{55}$ al destino y a sus avatares, quedando consagrado él y sus vestiduras ${ }^{56}$, subió al trono un rey de nombre "profeta elocuente ${ }^{57}$ », al que los perversos consideraron despreciable, y del que los malvados decían: ¿cómo nos va a salvar éste? ${ }^{58}$ Sopló entonces un viento tórrido ${ }^{59}$ que barrió a toda la estirpe de los necios, y se convirtió en el salvador ${ }^{60}$ de la sabiduría, y por donde quiera que se dirigiera, vencía ${ }^{61}, \mathrm{y}$ el que había sido arrastrado, arrastraba ahora, y el que había sido empujado, empujaba, y el pueblo que huía hacia el desierto se revolvía contra sus perseguidores ${ }^{62}$.

50 En la ed. תקרא vocalizado como Nifal. Tanto por el contexto, como por el metro del verso, creemos que es mejor mantenerlo en Qal; seguramente esta es también la lectura del ms. pues no indica la yod, como suele hacer el copista con todas las matres lectionis.

51 Cf. Sal 62,6.

52 Nú 24,3.

53 Según Geiger (Otsar Nehmad 2, pág. 161) y Schirmann («Les contes rimés», pág. 285, n. 2) se refiere al año 4993 (1233 e.C.); esto ha permitido datar la composición del Sefer ha-Mešalim en torno a esta fecha. Es ésta una época dramática para las comunidades judías, que se ven envueltas en un encarnizado enfrentamiento entre partidarios y detractores de Maimónides, tras la prohibición del estudio de sus obras por parte de los talmudistas de Montpellier, encabezados por Selomó de Montpellier en 1232. Quizás el relato de Jacob quiera reflejar esa época con más realismo del que hasta ahora se haya pensado: la lucha entre la clase aristocrática e intelectual pro-maimonideana -entre la que podemos suponer que se encontrarían los mecenas de nuestro autor-y los talmudistas tradicionalistas del norte de Francia, apoyados por muchos líderes religiosos de las comunidades judías. Precisamente hacia 1233 llegó a Castilla, procedente de Narbona, David Qimhí, con la intención de obtener cartas de los principales representantes de la comunidad para lanzar un anatema contra los antirracionalistas del grupo de Selomó de Montpellier; cf. BAER, Historia de los Judios, págs. 102 ss. y n. 66; B. Septimus, Hispano-Jewish Culture in Transition. The Career and Controversies of Ramah (Cambridge, Mass. 1982), págs. 39 ss.

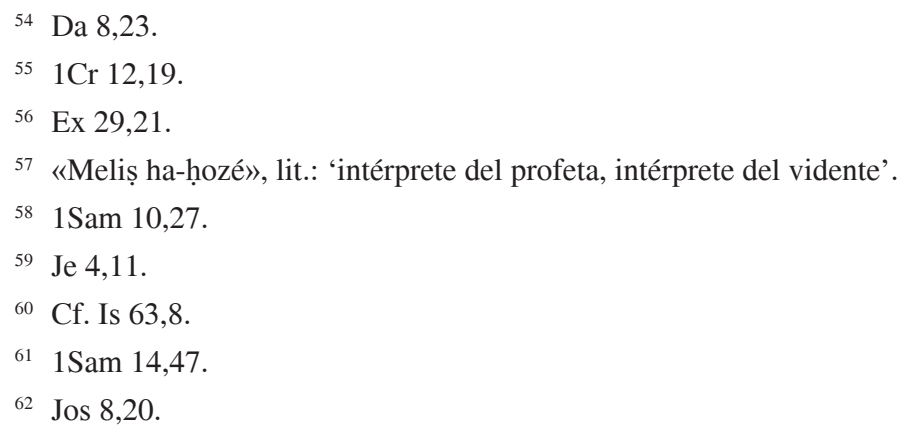


Pronuncié el siguiente poema ${ }^{63}$ :

El sabio ha acabado con la necedad, ante él los ignorantes se aterrorizan y diariamente la diestra del Poeta despedaza a los necios, hasta que los ignorantes han llegado a su fin $\mathrm{y}$ han sido reducidos al silencio los faltos de inteligencia ${ }^{64}$.

Edificó para las ciencias ciudades almacenes ${ }^{65}$ y remozó los templos de la sabiduría y sus recintos; nombró a hombres fieles y a sus seguidores y estableció ramas del conocimiento con sus escuelas. Y algunos de los que, por su sabiduría, se habían ocultado o alejado, salieron de las cavernas en las que se habían escondido ${ }^{66}$. La inteligencia se asentó en su trono y en su pedestal y plantó las tiendas de su palacio ${ }^{67}$. Cuando la inteligencia y la sabiduría estuvieron prestas, abrieron a los sedientos sus manantiales, y brotó agua viva ${ }^{68}$ de su fuente. Bebió la comunidad y su ganado ${ }^{69}$, incluso los necios calmaron su sed como ciervos, y apagaron su sed los onagros ${ }^{70}$.

Y pronunció el siguiente poema ${ }^{71}$ :

Los poetas han entonado cánticos de alegría por las fuentes de la sabiduría, que se han abierto para que bebieran los sedientos; también los necios han bebido hasta saciarse ${ }^{72}$ y han satisfecho sus anhelos.

Por eso nos ha quedado el proverbio: ¿también los necios están entre los profetas? ${ }^{73}$

63 Metro hebreo del poema: ha-marnin.

64 Cf. Is $5,13$.

65 Ex 1,11.

${ }_{66}$ Traducimos conjeturalmente este pasaje, muy dudoso desde el punto de vista sintáctico y semántico.

67 Da 11,45 .

68 Gé 26,19.

69 Nú 20,11.

70 Sal 104,11.

71 Sic en ms. Pero en la ed. David pone la expresión en 1. a persona, sin indicar la razón ni hacer ninguna anotación. Metro hebreo del poema: ha-merubbé.

$72 \mathrm{Ab} \mathrm{1,16.}$

73 Cf. 1Sam 10,11. 
Mi alma oyó hablar de su sabio entender y salió a comprobarlo, a ver a la Sabiduría con todo su esplendor y riqueza para servirla y protegerla ${ }^{74}$. Entonces vi a una mujer que descendía desde la cumbre del Amaná ${ }^{75}$ hacia un manantial, en el camino de Šur ${ }^{76}$; mi alma corrió a su encuentro, ansiando y apeteciendo las aguas de su sabiduría y ella bajó a la fuente y sacó agua ${ }^{77}$. Enardecido mi corazón, recorrió los senderos y las calles de la inteligencia, para reparar los deterioros ${ }^{78}$, las ruinas y los escombros ${ }^{79}$. Era al atardecer, al tiempo en que salen las aguadoras ${ }^{80}$, que es cuando normalmente el sabio descubre los secretos y arcanos; al anochecer, a la caída del día, al tiempo de la noche y de la oscuridad ${ }^{81}$, que es la que aguza el entendimiento hasta quebrar sus barreras ${ }^{82}$; entonces sus pensamientos se agitan como espadas, más vivaces que lobos nocturnos ${ }^{83}$.

$\mathrm{Y}$ entonó estos versos ${ }^{84}$ :

$\mathrm{Al}$ atardecer, cuando salen los que sacan agua de sabiduría del manantial del pensamiento, es cuando las mentes se funden en la elocuencia, más agudas que lobos nocturnos, cuando se les revelan las maravillas del pensamiento a los ojos del corazón, no a las pupilas.

Mientras las mentes de los necios dormitan y se acuestan ${ }^{85}$, $\operatorname{las}^{86}$ de los rehenes corren inquietas por deleitarse en la dulzura de los santos y buscar al que escruta los corazones. Y si ves a los necios indagando, no te equivoques: sólo están consultando a los nigromantes ${ }^{87}$.

${ }^{74}$ Gé 2,15 .

${ }^{75} \mathrm{Ca} 4,8$.

76 Gé $16,7$.

77 Gé 24,45 .

$782 \operatorname{Re} 12,13$.

79 Cf. Is 49,19 .

${ }^{80}$ Gé 24,11 .

${ }^{81} \operatorname{Pr} 7,9$.

82 Tal como lo vocaliza el editor 'sus escorias', 'sus impurezas'; parece más probable que se trate del plural de סיג ('Sus cercas, sus límites').

83 Ha 1,8 .

${ }^{84}$ Metro del poema: ha-merubbé.

${ }^{85}$ Cf. Is 56,10 .

${ }^{86}$ Lit.: 'los corazones de los cautivos'.

${ }^{87}$ Cf. Is 8,19 . 
Hasta aquellos días la sabiduría no se había casado ni había sido sorprendida con varón ${ }^{88}$, era una doncella sin desposar ${ }^{89}$. Mi corazón contemplaba absorto a la sabiduría que salía con su cántaro al hombro ${ }^{90}$; cuando el pensamiento la encontró, corrió tras ella y la introdujo en las cámaras de su mente, la tomó a la fuerza ${ }^{91}$ cuando ella salía de su sitio, la agarró y yació con ella ${ }^{92}$.

Y proferí el siguiente poema ${ }^{93}$ :

Mi corazón yació con la sabiduría cuando la encontró en la estancia del pensamiento; ella gritó, pero no tuvo quien la socorriera ${ }^{94}$ ni quien le diera respuesta.

La llamaron prostituta; pero yo digo ${ }^{95}$ que es una esclava que me he comprado ${ }^{96}$, y por la que he pagado ${ }^{97}$; entonces respondió ella: tú ${ }^{98}$ eres natural de mi pueblo y los demás ${ }^{99}$, forasteros y mercenarios ${ }^{100}$. el sabio se casará con la dotada de gracia pues sobre trono de gloria su corazón se asienta y el necio desposará a la hija de un dios extranjero ${ }^{101}$ pues el corazón del necio vuelve al muladar.

\footnotetext{
88 Cf. Nú 5,13.
}

89 Ex 22,15.

90 Gé $24,15$.

91 2Sam 13,11.

92 De 22,28.

93 Metro del poema: mišqal ha-tenu'ot.

94 Cf. De 22,27.

95 Corrijo, siguiendo el ms., a David que vocaliza (אמר) en 3. persona.

96 En la ed. aparece la forma אתכנה, en Hitpael; por contexto traducimos en voz activa como si se tratara de una forma Piel.

97 Lit.: 'su dinero ya ha sido restituido por mí'. En la base de estos versos se encuentran las disposiciones relativas a la joven virgen que es forzada en el campo; la obligación del hombre que la forzó es pagar al padre de la muchacha una cantidad de dinero y quedarse con ella como esposa de la cual no se podrá divorciar. Cf. De 22,28-29.

98 En la ed. aparece vocalizado (et) con segol, como si se tratara de la nota de acusativo; es un error de lectura por את (at), el pronombre personal de 2. ${ }^{a}$ persona.

99 Lit.: 'pero excepto tú'.

100 Cf. Ex 12,45.

101 Mal 2,11. 
La sabiduría se dirigió a su escuela en compañía de su esposo ${ }^{102}$. Cuando mi corazón caminaba en compañía de su esposa, la sabiduría, era como el esposo que sale de su baldaquín ${ }^{103}$ y pasea por entre los huertos y jardines de ella ${ }^{104}$, entre sus lirios y arrayanes, entre su hierba y su mirra, aspirando sus fragancias, y deleitándose en sus granados y manzanos, en sus brotes y en sus flores.

$\mathrm{Al}$ alzar la vista por encima de los mirtos y las flores, vio a dos hombres hebreos que reñían ${ }^{105}$. El uno era un valiente guerrero; su rostro era como el de un león, ceñía una espada sujeta a sus caderas ${ }^{106}$, daba gritos y alaridos ${ }^{107}$ y espantaba a todos cuantos lo veían; su bramido era como el rugido de las aguas del abismo: rugía como los cachorros, bramaba ${ }^{108}$.

Recitó ${ }^{109}$ los siguientes versos ${ }^{110}$ :

¿Hay algún valeroso joven que se me parezca

y que pueda hacerme frente ${ }^{111}$ ?

Reyes y soldados tiemblan ${ }^{112}$

cuando me desenfundan.

En la mano del otro ${ }^{113}$ había un cálamo; no teme ante su voz ni a su clamor se achanta.

Entonó su poema ${ }^{114}$ y dijo ${ }^{115}$ :

¡Tonto! Ponte la mano en la boca ${ }^{116}$ y cállate porque

te puedo destruir con la boca de mi cálamo y mi caña;

${ }^{102}$ Lit.: 'su esposo la acompañó', como en 2 S 3,16.

${ }^{103}$ Sal 19,6.

104 Qo 2,5.

105 Ex 2,13.

1062 Sam 20,8

107 Is 42,13 .

108 Is 5,29 .

109 Corrijo, según ms., a David que reproduce una 1 a $^{\mathrm{a}}$ persona del verbo en vez de la $3{ }^{\mathrm{a}}$.

110 Metro del poema: ha-merubbé.

111 Cf. Je 49,19.

112 Sal 104,29.

113 El texto dice אחד; quizás sería mejor אחר.

114 De nuevo corrijo, según ms., a David que interpreta el verbo y el sufijo pronominal en $1 .^{\text {a }}$ persona, en vez de en $3 .{ }^{a}$.

115 Metro del poema: ha-merubbé.

116 Cf. Ju 18,19. 
¿no se te ha enseñado desde antaño

que con la espada nadie se salva ${ }^{117}$ ?

El que llevaba la espada se acercó al que tenía el cálamo y le recriminó ${ }^{118}$ en estos términos: ¿qué es el cálamo para gloriarse entre las cañas, donde no crecen más que cardos ${ }^{119}$ ? ¿Acaso no nace y se cría escondido entre las cañas del pantano ${ }^{120}$ ? Apesta el olor de su tuétano y pierde su verdor el mismo día en que lo cogen, y se vuelve amarillento y mustio. Si no se (les) saca punta ${ }^{121}$, sus cuerpos se hinchan como odres abrasados por el solano ${ }^{122}$. De no ser por las espadas, las cañas no tendrían corazón, pues hay que llegar hasta su punta y cortarlas con las espadas ${ }^{123}$; sus bocas fueron abiertas para orar, y el espíritu reposaba sobre ellas ${ }^{124}$, o para consignar por escrito, como hasta ahora, los pecados y las faltas ${ }^{125}$ en el libro de las memorias ${ }^{126}$; incluso han trascrito sentencias perversas ${ }^{127}$; todo esto está escrito en tu libro ${ }^{128}$. ¿Cómo puede llamar «tonta» a la espada el que come en los montes ${ }^{129}$, y al que yo corté ${ }^{130}$ cuando era insignificante y vil, y alzarse contra mí, al acecho, como ${ }^{131}$ hace ahora ${ }^{132}$ ?

\footnotetext{
117 Cf. 1Sam 17,47.

118 Je 39,5. Lit: 'Pronunció sentencia contra él'.

119 Pr 24,31; hay que corregir el texto de la edición, que trae כמשונים en vez de קמשונים.

$120 \mathrm{Jb} 40,21$.

${ }^{121}$ Lit.: 'no se aguzan los filos', como en Qo 10,10.

122 Gé 41,6.

${ }^{123}$ Ez 23,47; en la ed. aparece el verbo vocalizado como Qal, 'crear’; en el texto bíblico, en
} Piel, 'cortar'.

124 Nú 11,26.

125 Aunque no se ve con claridad en el ms., propongo corregir el término שגיונות en la ed. de David, por el de שגיאות, 'falta o pecado involuntario', por coherencia con el término anterior.

126 Cf. Est 6,1.

127 Cf. Is 10,1 .

128 Sal 139,16 .

129 Ez 18,11; hay que corregir la vocalización del verbo en voz pasiva, que propone David, por la forma activa, como en el texto bíblico. La incursión de esta cita sugiere que la espada está acusando al cálamo de idólatra, pues el contexto bíblico alude a los que comen en los altos el alimento sagrado.

${ }^{130}$ La ed. vocaliza el verbo en forma Qal ('crear'); proponemos su corrección a Piel ( 'cortar'), como más arriba, nota 123.

131 1Sam 22,13.

132 Gé 39,11; De 6,24. 
Y entonó este poema ${ }^{133}$ :

¿Llamas necia a la espada

cuando no hay nadie más necio que el tonto cálamo?

¿Acaso el cálamo y la caña

no sirven de alimento ${ }^{134}$ a la espada?

¿Es que la paja seca ${ }^{135} \mathrm{y}$ el tamo que se dispersa ${ }^{136}$

van a devorar a la espada bruñida ${ }^{137}$ ?

¿Qué poder va a tener el cálamo si

sólo puede atacar con tinta?

Respondió el cálamo diciendo con ciencia y elocuencia: ¿qué ${ }^{138}$ es eso que denigra el consejo ${ }^{139}$, y quién maldice y es insolente? Gentuza con espadas por dientes ${ }^{140}$ que ni entiende ni conoce, todo simpleza, no sabe nada ${ }^{141}$. ¡Llaman cañas a los cálamos porque proceden de ellas! Pues por el nombre de sus hermanas los están llamando. En tu ignorancia has pensado frívolamente, como un perturbado, que el insensato se hará cuerdo ${ }^{142}$; atacas a los objetos que están circuncidados ${ }^{143}$, pero ¿acaso no es hermoso su escrito y su escritura cuando se le circuncida la carne de su prepucio? Menosprecias mis raíces porque brotan junto a los ríos: al olor de su agua reflorece ${ }^{144}$; pero si contase cómo naciste tú, ten por seguro que no redundaría en gloria tuya: recuerda tu nacimiento y no olvides que el hierro se extrae del polvo ${ }^{145}$.

Y pronuncié estos versos ${ }^{146}$ :

Baja y vuelve al polvo, y no

te enaltezcas ${ }^{147}$, pues ¿cómo va enorgullecerse la espada

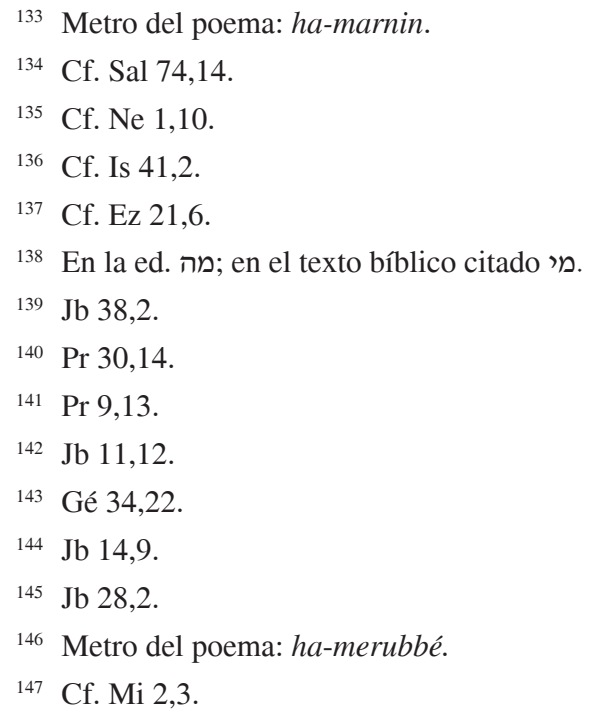


si es polvo? Arderá su polvo

cuando el sol más caliente ${ }^{148}$, se abrasará en el suelo ${ }^{149}$.

Al oír esto la espada se alzó airada, salió de su vaina y dijo: ¡Ay de los cálamos como me enfrente a ellos...! ¡Como blanda la espada contra ellos...! Disfruta de tu gloria y quédate en tu casa ${ }^{150}$, no tenga que salir con la espada a tu encuentro; no te vanaglories ${ }^{151}$ de tu conocimiento e inteligencia; ¿por qué quieres buscarte problemas ${ }^{152}$ ? Mira que si abro la boca silenciaré tus alardes y tu graciosa figura ${ }^{153}$ y haré que se te pegue la lengua al paladar ${ }^{154}$. ¿Te has imaginado que soy como tú ${ }^{155}$ ? En absoluto, pues la espada es la gloria de los reyes, el siervo de los príncipes y la protectora de los perplejos; da vida al que la empuña y es ayuda contra sus enemigos ${ }^{156}$; para todo aquel que me ciña a su flanco ${ }^{157}$ seré una ayuda apropiada ${ }^{158}$. Mis enemigos se harán fuertes si me escuchan y colaboran conmigo, pero si no me escuchan, de un tajo morirán ${ }^{159}$.

Y pronunció estos versos ${ }^{160}$ :

Triunfo en todos los lances de fuerza, ¿quién puede enfrentarse a mí y seguir vivo?

Soy la salvación en mano de príncipes y mendigos;

he sido enviada a los débiles como sustento.

De día estoy junto a los hombres, y por la noche

soy como casco y corona en sus cabezas ${ }^{161}$.

Los prefectos me llaman hermana

y los príncipes me han tomado por esposa.

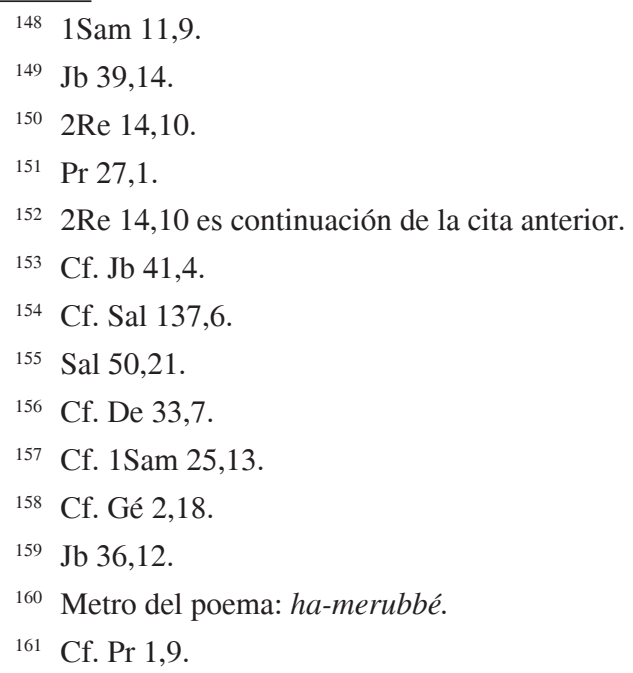


Mío es el poder y mío el trono de la realeza ${ }^{162}$, por mí es reconstruido su muro derruido; si yo no aniquilara a los traidores, y al que hiere por odio y por despecho ${ }^{163}$, la faz del universo se llenaría de gente falsa ${ }^{164}$ y de asesinos, y habría infinidad ${ }^{165}$ de cadáveres ${ }^{166}$. ¿Por qué, pues, el cálamo, tan insignificante y vil, se sube por las nubes, se jacta y se vanagloria de su sabiduría ${ }^{167}$ cuando sólo es un miserable, y su sabiduría, despreciable ${ }^{168}$ ?

Contestó el cálamo y dijo: Basta ya de ensalzarte y de vanagloriarte, recógete en la vaina, cálmate, cesa ${ }^{169}$; ¿por qué estás tan orgullosa de matanzas y asesinatos?, los enemigos han acabado hechos ruinas eternas ${ }^{170} \mathrm{y}$ has convertido una tierra habitada en un lugar devastado ${ }^{171}$. Vosotros, que os apoyáis en vuestras espadas, habéis cometido abominaciones ${ }^{172}$, y no sirve de nada ${ }^{173}$, pues son tantos los cadáveres ${ }^{174}$, que tiembla el corazón y aumentan los caídos ${ }^{175}$; de la boca de la espada ${ }^{176}$ mana sangre de inocentes ${ }^{177}$, de tantas víctimas como ha echado por tierra ${ }^{178}$. No has dejado vivo al inocente o al justo ${ }^{179}$, eres la ruina de tu nación.

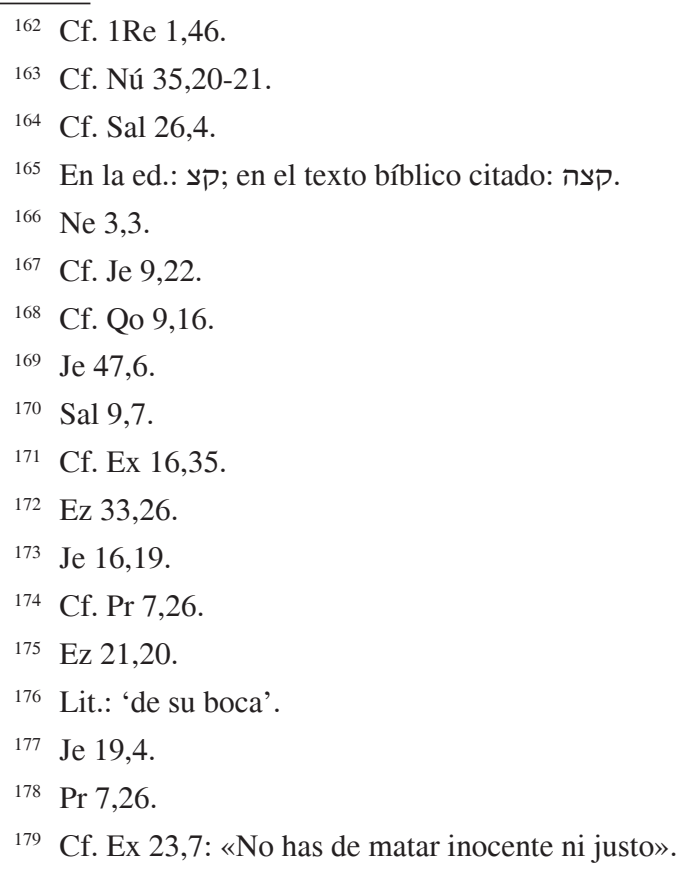


Pero cuando (el cálamo) abre la boca contra sus enemigos considera al arma arrojadiza como paja ${ }^{180}$ y cual tamo que dispersa el viento ${ }^{181}$ la arroja ${ }^{182}$ cuando habla. Reduce las espadas a polvo ${ }^{183}$, rompe $\operatorname{los} \operatorname{arcos}^{184}$ y hay que redoblar los esfuerzos ${ }^{185}$. Exterminan ${ }^{186}$ a los regimientos y a sus jefes en una hendidura de la peña de Etán ${ }^{187}$. Voy a abrir con parábolas mi boca ${ }^{188}$ y a aplastarlos con mi furia ${ }^{189}$ hasta que reconozcan humildemente ${ }^{190}$ que los he sometido; entonces forjarán de sus espadas arados ${ }^{191}$ y esperarán mis instrucciones ${ }^{192}$. Estos son los estatutos y las leyes ${ }^{193}$ : el que quiera pedir, que le pida a su cálamo, pues no dejará que le condenen cuando se le juzgue ${ }^{194}$.

Mi boca te dará a conocer lo que aconteció en el pasado ${ }^{195}$, la historia de los príncipes, reyes ${ }^{196}$ y sacerdotes que nos precedieron, hasta el punto de que tendrás la sensación de trabar amistad con cada uno de ellos. Su boca hablará a tu boca ${ }^{197}$ y te informará acerca de su justicia y lealtad ${ }^{198}$, y su perversidad y sus pecados ${ }^{199}$. De mi boca aprenderás doctrina y sagacidad y te enseñará secretos y sabiduría ${ }^{200}$.

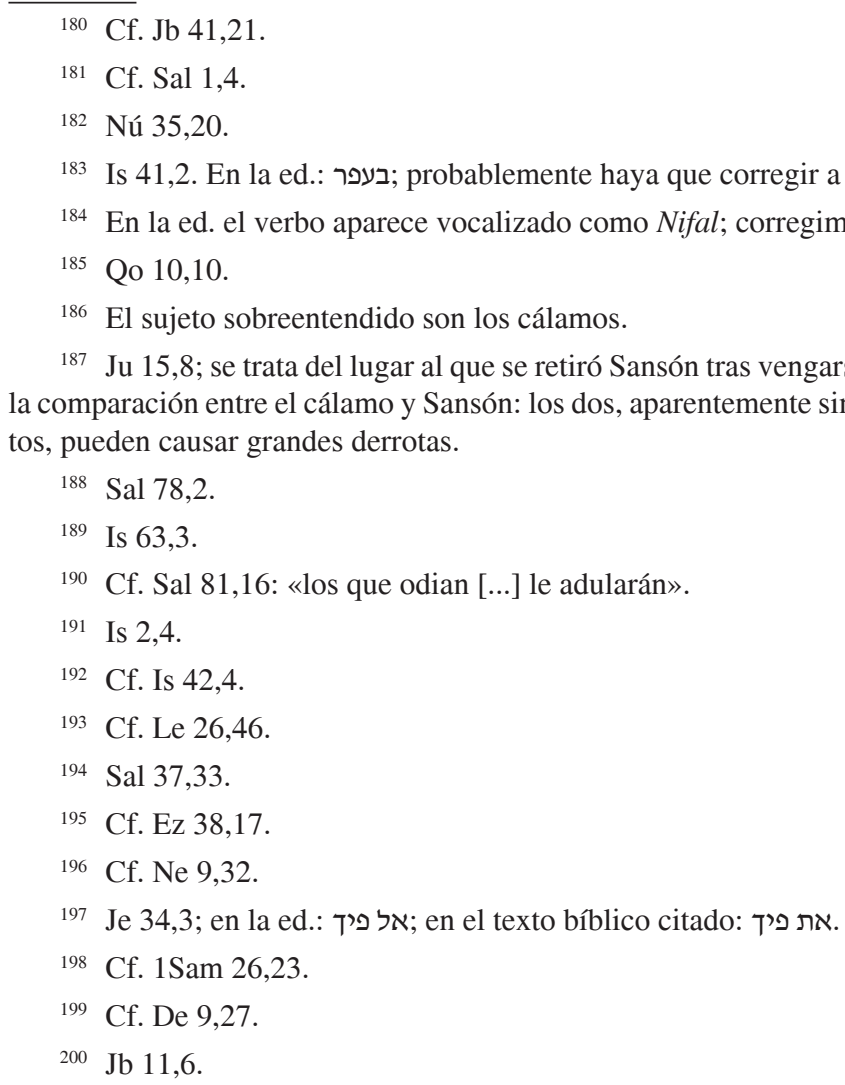
tos, pueden causar grandes derrotas.

187 Ju 15,8; se trata del lugar al que se retiró Sansón tras vengarse de los filisteos. Se establece la comparación entre el cálamo y Sansón: los dos, aparentemente sin grandes fuerzas ni armamen- 
Y pronunció el siguiente poema ${ }^{201}$ :

Yo soy fuerte y tengo señales de fuerza;

con la saliva de mi boca reduzco a mi enemigo a desolación ${ }^{202}$

pues, aunque el cálamo sea corto de estatura,

el dardo de su boca llega hasta los confines de la tierra ${ }^{203}$.

Yo, la Sabiduría, convivo con la Sagacidad ${ }^{204}$;

mi boca te descubrirá arcanos secretos ${ }^{205}$

y te informará de lo que hubo antes,

pero lo que ocurrirá, no lo puedo saber ${ }^{206}$.

Cuando la espada oyó su respuesta se arrodilló y se prosternó ante él ${ }^{207}$, y dijo: Dame un poco de tu sabiduría y extiende sobre tu servidora tus alas ${ }^{208}$. Como le implorara y le insistiera, se lo explicó para que le dejara tranquilo ${ }^{209}$.

Respondió el cálamo y dijo: Has de saber que la espada no es la más fuerte en la batalla, ni el que posee el cálamo tiene inteligencia ni sabiduría. Considera nulo todo el entendimiento que alberga en su corazón, pues la inteligencia se oculta de sus entendidos ${ }^{210}$; como nadería son mis sabios y mis entendidos, pues ni sabiduría ni consejo caben frente al Señor ${ }^{211}$.

Y pronunció el siguiente poema ${ }^{212}$ :

Abre mi libro y en él hallarás ciencia;

él te hará conocer el arte de la reflexión;

hasta que comprendas que tú no puedes

añadir o quitar nada.

Entonces sabrás y comprenderás que la suerte

del hombre es la misma que la de los animales ${ }^{213}$ :

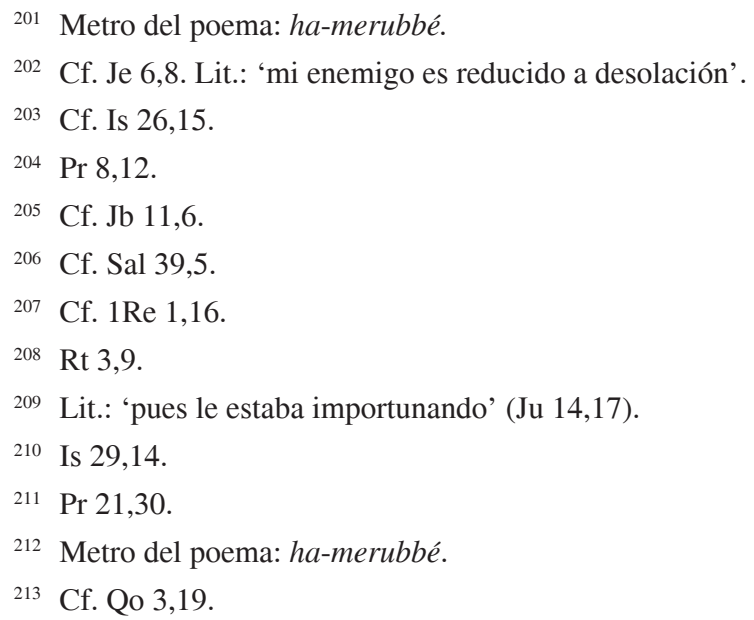


a la puerta de la muerte todos llegan;

pero nadie sabe lo que hay dentro.

Sólo perdura el que extiende los cielos

sobre el vacío y la tierra sobre la nada ${ }^{214}$.

Dijo la espada sorprendida: ¿Quién es ese señor terrible que tiene poder sobre todas las criaturas? Le respondió: Es el Señor, Dios de dioses y Señor de los señores ${ }^{215}$; el primero entre los primeros y el último entre los postreros ${ }^{216}$. Es el Uno por excelencia ${ }^{217}$ al que todas las cosas alaban; el que descubre la ciencia oculta y sus arcanos saca a la luz; que tomó ${ }^{218}$ un poco de sabiduría y le dio forma con el buril ${ }^{219}$.

Entonó el siguiente poema ${ }^{220}$ :

Ocho son los principios ${ }^{221}$ de todas las unidades ${ }^{222}$,

pero sólo de aquel en el que no se da pluralidad ${ }^{223}$

214 Cf. Jb 26,7.

215 De $10,17$.

216 Expresiones semejantes aparecen en Is 41,4; 44,6; 48,12.

217 Lit. 'El Uno de todas las unidades'. Comienza aquí un exordio acerca de las cualidades de Dios, el único Uno, en el que se mezclan conceptos filosóficos propios de su época (neoplatonismo y racionalismo). Terminología semejante encontramos en el Séfer ha-Šem de Abraham ibn 'Ezrá, en Los Deberes de los corazones de Bajyá ibn Paquda, y en Ibn Gabirol, tanto en su obra filosófica La Fuente de la Vida, como en el poema Keter Malḱt. En la obra de Ibn Paquda (arts. 7 y 8) aparecen con profusión textos sobre la unicidad de Dios (el Uno) frente a los otros «unos», o «unidades». En el art. 8 habla de la «unidad verdadera» y la «unidad metafórica».

218 En la ed. aparece el verbo en $2^{\mathrm{a}}$ pers.; tanto por el contexto como por la referencia bíblica a Ex 32,4 , corregimos a $3^{\mathrm{a}}$ pers.

219 Ex 32,4.

220 Metro del poema: ha-merubbé.

221 Lit.: 'Ocho son los orígenes, o principios [Abot] de todas las unidades'. Verso de difícil interpretación. Y. David confiesa en la primera ed. de este capítulo (en Katif) que no puede explicarlo; en la ed. de la obra completa, sin embargo, incluye en nota una referencia a una baraytá en la que se menciona a los siete «Padres» de Israel: «Abraham, Isaac, Jacob, José, Moisés, Aarón, David y el octavo es nuestro padre en los cielos». No parece que tenga mucha relación con nuestro texto, que enumera una serie de atributos o cualidades divinas, presentes en las obras de los principales pensadores judíos medievales.

222 Pienso que la referencia más probable de este difícil verso es a las categorías aristotélicas; si bien en las obras lógicas de Aristóteles se habla de diez categorías, en Metafísica (por ejemplo, libro Delta VII) menciona ocho, ya que dos de las diez pueden ser incluidas en otras. Por otra parte, parece que nuestro autor está haciendo una distinción entre la unidad accidental o metafórica y la unidad sustancial o verdadera; cf. Ibn Paquda, Los deberes de los corazones (Madrid 1994), pág. 45, lo cual encaja bien con la hipótesis de que se refiera a las categorías, que son principios de unificación de las realidades individuales.

223 La característica de las unidades, o individuos, es la pluralidad; del uno verdadero, la unicidad. 
se puede predicar que es Uno de verdad ${ }^{224}$, y es el Dios verdadero ${ }^{225}$, que desde antaño es refugio ${ }^{226}$;

y no está en ningún lugar, salvo en el pensamiento

del sabio y en el crisol de la razón.

Es un Dios vivo y eterno ${ }^{227}$, no tiene imagen,

ni forma, ni representación de ningún tipo.

Revea la ciencia oculta

y todo ser está a merced de El Sadday.

Él conoce el valor de todas las criaturas

y de Él procede toda la sabiduría.

Es el principio de todo y también el final.

Y es la causa de toda causa sublime.

En todas las unidades no hay unicidad ${ }^{228}$ como la de Él y aparte de Él, ¿no ves que todo lo creado es múltiple ${ }^{229}$ ? Todo lo creado posee espíritu y materia; toda materia dotada de forma es inteligible; tu espíritu es prueba de veracidad. Y fuera de Él todo lo que es llamado Uno, no es uno de verdad, sino falsamente, y muere ${ }^{230}$, en cambio el Señor es Dios verdadero ${ }^{231}$.

${ }^{224}$ O, según la terminología de Ibn Paquda (Los deberes de los corazones, pág. 43): ‘El Uno verdadero' (Ha-Ehad ha-Emet).

225 Sal 31,6.

226 Cf. De 33,27.

227 Cf. Da 6,27.

${ }^{228}$ En la ed. מאחר; consideramos que es una lectura errónea por מאחד ('unir, reunir, amalgamar'); estamos, en todo caso, ante un pasaje muy complicado del que no podemos ofrecer más que una traducción conjetural basándonos en obras filosóficas de la época, como por ejemplo, Ibn Paquda, Los deberes de los corazones, pág. 45: «la unidad es el principio de la síntesis [...] en el mundo existen muestras de composición [...] es necesario que se dé la síntesis y la diversidad, así como el fundamento de ambas: la unidad y la multiplicidad». También recuerda al segundo de los artículos de fe de Maimónides: «No hay otro como Él entre las unidades»; afirmaciones semejantes las encontramos en Ibn Gabirol (Keter Mal kut 2): «Tú eres Uno y no a la manera de la unidad adquirible y computable, puesto que no te alcanza ni multiplicidad, ni cambio ni acepción».

${ }^{229}$ Lit.: 'trescientos'; hemos supuesto que con este numeral se pretende aludir sólo a la «multiplicidad» que se da en los seres creados frente a la unidad del Creador. No hemos encontrado en fuentes rabínicas anteriores una justificación para esta ni para cualquier otra interpretación de este numeral. En Ibn Gabirol, La Fuente de la Vida (Barcelona 1987), tratado 3. ${ }^{\circ}, 19$ (22), pág. 174, encontramos: «Lo uno es la raíz de la multiplicidad. [... ] lo múltiple es un conjunto de unidades [...] las unidades son las partes de lo múltiple»; y 33 (7): «Toda forma une lo que es imaginado por ella; lo que une algo no lo multiplica».

${ }^{230}$ De nuevo se trata de distinguir entre el Uno verdadero y las unidades accidentales. En Ibn Paquda (Los deberes de los corazones, pág 44) : «la verdadera unidad no tiene ni comienzo ni fin, pues a todo lo que tiene comienzo y fin le afecta necesariamente la generación y la corrupción [...] la mutación es contraria a la unidad».

$231 \mathrm{Jr} 10,10$. 
Y pronunció el siguiente poema ${ }^{232}$ :

El Omnipotente ha de ser llamado en verdad Uno

no se le puede dividir en partes ni juntar ${ }^{233}$,

pues todo aquello que es llamado uno

es indivisible una vez que está unido.

El Uno que no se divide permanece

eternamente, pero la unidad compuesta, es perecedera.

No necesita ni desea nada ${ }^{234}$, pues toda la creación enseña a sus criaturas a servirlo; las enseña, pero no sobre los planes de Dios Altísimo ${ }^{235}$, porque no hay quien asista al consejo de Dios ${ }^{236}$ Altísimo. Él es Uno, que a los grandes de la tierra humilla ${ }^{237}, y$ destruye tanto al pequeño como al grande. Fíjate que ni siquiera los Santos del Altísimo, con toda su gloria, son dignos de su confianza ${ }^{238}$, cuánto más los moradores de casas de barro, que tienen sus cimientos en el polvo ${ }^{239}$; todos los seres inferiores ${ }^{240}$, todos, tropiezan, pero la justicia de Dios permanece eternamente ${ }^{241}$.

Recitó el siguiente poema ${ }^{242}$ :

La tierra, el Cielo y sus moradores, todos al Dios terrible ${ }^{243}$ rinden vasallaje.

Los seres inferiores y los superiores son ante los ojos de su Creador vanidad: ni el criado ni el noble pueden mantenerse ${ }^{244}$; sólo permanece

232 Metro del poema: ha-mahir.

233 Gran semejanza en estos versos con los de Ibn Gabirol en Keter Malkut 2: «Tú eres uno, y tu unicidad no mengua ni aumenta, nada le falta ni le sobra. Tú eres uno, mas no como unidad que se crea y se cuenta, pues no te alcanza multiplicidad ni cambio».

234 Lit.: 'caza no busca ni codicia'.

235 Lit.: 'Ignoto, recóndito', epíteto frecuente de Dios en este tipo de textos que reproduce el de Deus absconditus.

236 Cf. Je 23,18.

237 Cf. La 1,15.

238 Cf. Jb 4, 18.

$239 \mathrm{Jb} 4,19$.

240 Lit.: 'los habitantes de las profundidades de la tierra'.

241 Sal 112,9.

242 Metro del poema: ha-mahir.

243 Sal 89,8.

244 Cf. Is 24,2 . 
el Dios verdadero, pues la verdad no perece, porque la verdad no tiene fundamento en el ser creado: sólo Dios, el Señor, es la única Verdad.

En verdad, sus ángeles celestiales y sus Santos fieles y todos aquellos que se iluminaron con la luz de su Gloria original sólo empezaron a ser cuando el Rey de la Gloria lo mandó. Pues Él dijo y fueron hechos, Él mandó y existieron ${ }^{245}$, por eso, al tallarlos de su luz magnífica, los hizo estar ante el Señor para servirle ${ }^{246}$.

Y pronunció el siguiente poema ${ }^{247}$ :

No existen en acto, sino en potencia, pero ¿acaso la potencia no está próxima al acto? ${ }^{248}$

El que saca a la luz lo oculto ¿no es él también

su causa? ¿no lo hizo y lo modeló?

En verdad, toda la creación está orientada a un final y el Creador puede destruirla. ¿No es cierto que si de repente Dios lo deseara, castigaría a los ejércitos celestiales ${ }^{249} y$ se diluirían ${ }^{250}$ como agua, y los cielos se enrollarían como un rollo ${ }^{251}$ ? Por eso creó los cielos en forma de esferas, para que permanezcan mucho tiempo; todo lo que puso entre tierra y cielo se consume y se acaba y todo lo que hay en la tierra muere ${ }^{252}$.

Y dijo el siguiente poema ${ }^{253}$ :

Él es el Creador, y puede destruir toda su creación si lo desea, y todo el universo desaparecerá;

245 Sal 33,9.

246 Cf. De 10,8. En la cita bíblica se refiere a los levitas, pero en este contexto la referencia es a los ángeles.

247 Metro del poema: ha-merubbé.

${ }_{248}$ Ibn Gabirol, La Fuente de la Vida, tratado 3.․, 21 (28), pág. 180: «las formas que se encuentran en la sustancia compuesta pasan al acto [...] cuando una sustancia simple se une a una compuesta, las formas que están comprendidas en ellas pasan de la potencia al acto».

249 Is 24,21 .

${ }^{250}$ Cf. Ju 15,14 e Is 34,3 .

251 Is 34,4 .

${ }^{252}$ Maimónides dedica un capítulo en Guía de perplejos (II, 29) a esta cuestión: la posibilidad de que Dios decidiera en un momento dado poner fin a la creación. Sostiene que la idea de la destrucción del mundo es contraria a la religión, e interpreta los pasajes bíblicos que se refieren a ella como metáforas. Jacob ben Eleazar parece coincidir con Maimónides («no las creó [las cosas] para ser destruidas»), a pesar de insistir en la idea de la omnipotencia divina («es el creador, y destruirá todo lo creado cuando lo desee»).

${ }^{253}$ Metro del poema: ha-mahir. 
todas las cosas que están bajo el cielo fueron creadas para consumirse y para ser como holocaustos; pero como las creó de su Gloria, no las creó ${ }^{254}$ para destruirlas, aunque si quisiera acabar con ellas, lo diría, y al momento las entregaría a la destrucción: el alfarero hace con su obra lo que quiere: la mantiene o la destruye, la levanta o la humilla.

Rebuscaron los corazones de los hombres ${ }^{255}$ y repasaron las calles ${ }^{256}$ de la ciencia según sus principios naturales, investigaron y estudiaron todo cuanto existe y discurrieron por las sendas del intelecto para contemplar toda la figura ${ }^{257}$; estaban asustados y temblorosos ${ }^{258}$ porque no sabían lo que era ${ }^{259}$. Cuando todos se pusieron de acuerdo, su sabiduría se despertó de su sueño, el pensamiento se purificó y el intelecto iba y venía, y se afanaba por elevarse a conocer la ciencia del Altísimo ${ }^{260}$, hasta encontrarse con el meollo ${ }^{261}$. Pero se fatigaron en vano por hallar la entrada ${ }^{262}$, pues no se puede conocer su naturaleza por medio del entendimiento; ni siquiera sus ángeles, que son de una sustancia pura y superior, pueden contemplar más allá de su Gloria, y no pueden comprender su secreto, sino sólo su majestad, con mayor razón los corazones humanos. No obstante, podemos verlo en lo profundo del corazón y en el crisol del pensamiento, y lo podemos encontrar en las cosas cercanas.

El es, en verdad, el origen de todas las unidades; hizo el alma animal y la vegetal, y el alma racional ${ }^{263}$, que brota y florece en el hombre y es como una vid en flor. Y le dio

${ }^{254}$ En la ed. «no las crearon» o «no fueron creadas», aunque esta última lectura, en hofal, es más difícil de admitir por cuestiones métricas.

$255 \operatorname{Pr} 15,11$.

256 Je 5,1.

257 Por los versos siguientes ¿podemos deducir que se refiere a Dios? Cf. Nú 12,8: (Moisés) contempla la figura del Señor.

258 Cf. Is 44,8 .

259 Ex 16,15. En Kéter Malḱkut, trad. J. M. Millás VAllicrosA, La poesía sagrada hebraicoespañola (Madrid-Barcelona 1948), pág. 205: «los sabios de corazón se asombran, pues no saben lo que es».

260 Nú 24,16.

261 Cf. Ez 24,4: «las mejores tajadas».

262 Gé 19,11. Ver también Maimónides, Guía de los perplejos III, 51.

263 Según la filosofía aristotélica, el alma vegetal y el alma animal son las dos almas inferiores que se encuentran tanto en el hombre como en los animales. 
huesos y nervios ${ }^{264}$, tres cálices en forma de flor de almendro ${ }^{265}$; Él es el único cuya majestad cubre los cielos ${ }^{266}$, y Él ha hecho todo cuanto existe ${ }^{267}$.

Al oír toda esta ciencia, la espada tembló y se cubrió de espanto, y dijo al cálamo: bien has hecho en enseñarme, tú eres más justo que yo ${ }^{268}$; ¿qué pueden hacer las espadas contra los cálamos? Efectivamente, la sabiduría da más fuerza al sabio que diez poderosos ${ }^{269}$; ¡qué dulce es tu discurso ${ }^{270}$ y qué agradable! Más vale la sabiduría que armas de guerra ${ }^{271}$.

Recibido: 25/01/2007

Aceptado: 23/10/2007

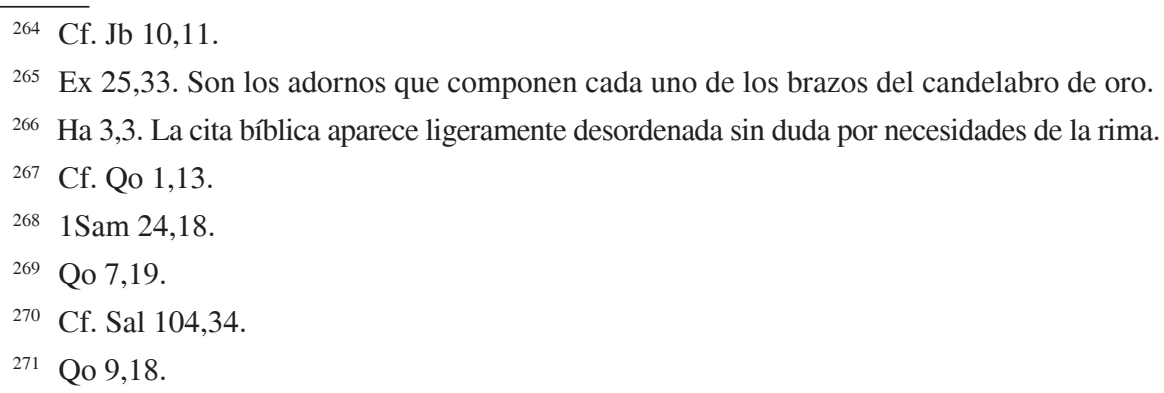

